\title{
E-Government Service in Singapore and Indonesia
}

\author{
Anton Minardi \\ Faculty of Social and Political Science \\ Pasundan University \\ Bandung, West Java 40261, Indonesia \\ abdurrahmananton1975@gmail.com
}

\begin{abstract}
This article intends to describe the implementation of e-government in recent era in managing public services and early problem preventions as part of political affairs. Recently, there have been two most advanced countries in egovernment service namely South Korea as the first rank and Singapore as the tenth world rank. For the contribution to my own country, I would like to write this article based on Indonesia's figure of e-government compare to Singapore as the neighbour and the tenth world e-government rank based on rights to information access. Thus the discussion will include human rights and the rights concept to information access, e-government conception, e-government in Singapore and Indonesia, personal privileges security, the impacts of e-government, cybercrime and law enforcement
\end{abstract}

Keywords: E-government service, rights to access information, personal privileges security

\section{INTRODUCTION}

The newest public service tends to develop from a new public management to digital era government. If in new public management was driven by inputs, goals, and costumers satisfactory, e-government can provide public service simpler, fast and connected with other public management. In other words, egovernment offers easy access for citizens and allow people involvement in governmental issues. Moreover in this era government can operate monopulse radars system to search and follow the target to control and reach it. Monopulse radars are systems used to track the position of moving targets. The system can produce clearer signal with the provision of both sum and difference signals by monopulse antennas [1] For efficiency in cost and space, the new antennas as single array antennas were created which afford to eradicate over than single pattern in various applications [2].
This comparative study of e-government portrays how government effort to satisfy their citizens with nearest and fast path to interact and communicate include among government biros, corporates and individuals with the case of Singapore and Indonesia. The reasons forchoosingthe comparison between Singapore and Indonesia are, first, both of them are developing countries situated in the same region, Southeast Asia. Secondly, these two states use a democratic system which concernson public service affairs. Third, both states have large internet literacy, Singaporean more accustomed to the internet in their business and young Indonesian generation, in particular, are large internet users in the world. Forth, Singapore and Indonesia have national information system based on their law. Fifth, both states are undertaking dispute resolution in the case of stagnancy, abusement, destruction and lack of information. The comparative research also purposes to gain the new meaning and technique for future advantages for both states, especially for Indonesia.

This article aims to find the types of e-government provides a right that meets the citizen needs to access information and how they communicate through egovernment. The article also analyses the security of personal privilege and how a law enforcement ensure information transparency effectively implemented on behalf of citizen and government benefit.

\section{RESULTS AND DISCUSSION}

The research finds several important points including following matters. Firstly, access to information is the fundamental human rights for increasing knowledge, carrier and high life quality or at least for upgrading better life. Secondly, e-government service provides government performance as an open, transparent and accountable system which would result in citizens satisfactory. Thirdly, e-government 
opens wider public involvement in governmental affairs. Fourthly, in information openness law or the Act was covered both sides for citizens and government to secure their interests including personal privileges. Fifthly, to gain effective implementation of e-government service including information openness, the system has been supported by upgrading citizens to internet literacy, egovernment managers or human resource skills and involvement in governmental affairs. Sixthly, egovernment service resulted in better citizens communication and interaction with the government. Seventhly, the implementation of e-government satisfies Singaporean and lead to economic improvement in Indonesia.

\section{Information Access as the Fundamental Human Rights}

In 1945 UNESCO had the mandate to support ideas and image freedom. The UNESCO implement its mission in Medium-Term Strategy for 2008-2013 (34 $\mathrm{C} / 4$ ) and especially to increase open access to information and knowledge. It endorsed the Dakar Declaration on Media and Good Governance (2005), access to Information and Empowerment of People (2008), a Freedom of Information (FOI) in Information Society World Summit, then FOI has been emphasized in Brisbane Declaration entitle Freedom of Information: The Right to Know (2010), the Maputo Declaration on Freedom of Expression [3]

UNDP mentioned that access to information is important for nurture transparency, accountability, and participation in good governance. It will bolster citizens to involve further in the decision-making process, such as actively in free and open essential debate to maintain pluralistic regimes. UNDP also promote all countries to open information access for all citizens for deep involvement to the Development process [4].

To information access, all citizens have to know what kind of documents are held by the government and how to request it. Furthermore, they have to know when their request has been coming into arbitration procedures. Also important to be brave to request their right to access the information as their needs. Contrary, in fact, some experiences that although they have information rules there found a barrier that even from well-educated realm they fear that their information requests will bother the good relations to government officials [5]
On June 1999, ARTICLE 19 published, The Public's Right to Know: Principles on Freedom of Information Legislation, give a suggestion how the practice of FOI in some countries comparatively. Their goal is to endorse the campaign for information legislation progressively and effectively. Eventually, The ARTICLE 19 intend to enter the UN Commission on Human Rights in 2000 session to promote the ideas concern on Freedom of Opinion and Expression [6]

As the basic foundational standard of information, legislation should underline the principle of maximum disclosure, establishing a broad presumption in favour of disclosure limitation in wide areas of public institutions. There are three principles remined as positive obligations on public authorities in this area. The first is to publish certain types of material, even in the absence of a specific disclosure request including information about the institution functions and decision-making process in the public institution and the types of information they maintain. The second is to bolster open government practice including public educations and officials training. The third is access to information should coverage the important of transparency and accountability whilst maintain whole security interest both citizens and state sovereignty and personal privileges.

Access to information only remains to be refused to refer to law and base on exceptions listed by courts and such an information boards for harmful reasons and to protect greater interests. An information access can run a set of procedures with considering the principle of easiness, simple way and cheap cost [7]

\section{Rights to Information Access in Singapore and Indonesia}

Singapore accepted 84 of 112 recommendations made by the Member States at its first UN Human Rights Council review, Singapore rejected recommendations regarding: media freedom, the protection, and promotion of the right to freedom of expression, the protection and promotion of the right to peaceful assembly and association. ARTICLE 19 protests this proceeding and also protests that Singapore denies to ratify the International Covenant on Civil and Political Rights (ICCPR) and arrest without trial based on the Internal Security Act [6].

Singapore currently has no obligation to answer any requests for information. When the requesters had a barrier in their information need, they can follow in courts mechanism or ombudsmen body to decide 
provision of information. President Ong has emphasized a relevancy of an information legislation to support freedom of information (FOI) to make the government more accountable and responsive. The information openness will bolster transparency and accountability [8]

Since the reformation 1998 Indonesia supported the implementation of a set of human rights protection including access to information. Since the reformation, civil activists endorsed for information freedom to legislation and it resulted in regulation under the Law No 14, 2008 Act for Public Information Openness. The Act covers both government interests and also citizens interests. Under the Act, everyone has rights to access of all kinds of information, and the other hand government is also protected from abuse and misuse of information. Citizens could be persons or organizations whom can access any kind of information including laws, programmes, budgets, policies and its implementations. The meaning of access to information is a wide meaning except for some information that could endanger to the state such as intelligence and military information, country resources, information in employing and investigation process both in police and trial, information of the negotiation process in order to internal and foreign affairs, and also personal information as personal privilege such as inheritance testaments, bank accounts, personal education and personal healthy story excluding for public officials.

The Act guarantees citizens to get their need for information and also protect the government from any extortion that is emphasized by some obvious sanctions articles. There are sanctions for government officials who ignore their obligation, and also for citizens who misuse or damage the information. Nevertheless the regulation have been obvious, there are still some barriers that practically invites debate by on-duty officials and citizens in different perspectives.

To access to information both Singapore and Indonesia had implemented e-government system. According to the UNDP, the goal of e-government implementation is to provide information for stake holders in the country include citizens, businessmen, and government itself. The UNDP mentioned that egovernance involves a public investment in information and communication technologies (ICTs) to strengthen governance processes. Access to and use of ICTs can provide new and innovative communication channels that empower people and give voice to those who previously had none while allowing them to interact via networks and networking [4].

\section{E-Government}

E-Government is strongly influenced by the expectations of the citizens to see public services provided in the same mode that is provided by so many entities in the private sector. Business organizations demandthat the government, one of its stakeholders, interface with them in the same way they interact with other private sector organizations. Also, government agencies are under the influence from other government agencies to enable electronic data interchanges (EDI) and other facilities that makethe e-government possible. So, the productivity that they promised will be earned [9]

E-government is not a goal solely; it should be viewed more as a means of organizing the general government to better serve citizens and companies. E-Government concerns the whole scope of the administrative measures, and the political process is linked because ICT is the enabling power that will increase the effectiveness, quality, and efficiency of public actions and legitimacy. The vision is that eGovernment in the modernization of public management will increase the value of the public. The creation of public value includes various roles: democratic, social, economic, environmental and administration of government. Specific examples of the role of public administration services cover the provision, implementation and evaluation of policies and regulations, guarantee the democratic political process [10]

E-government gave an alternative service for accessing to government information into government and administration level. E-government provided more efficient service for citizens through one-stop government portals. Moreover that egovernment "the current digital environment allows public agencies to not only deliver information to individuals, but also integrate levels of service that allow for direct contact with specific individuals or bureaus in an agency, financial transactions, and even social networking” [11]

Singapore has performed advance e-environment and infrastructure. It is a gateway to South East Asian markets and Proactive e-government and e-commerce related government initiatives (Basu, 2004). Singapore has developed e-government with five thrusts targets and six programs. The five thrusts targets are (1) providing more e-services, (2) building 
new capability and new capacity to sustain the operation of e-government, (3) being innovative and creative to prevent deploying outdated technology, (4) being sensitive and responsive to customers, and (5) demonstrating leadership and political willingness. The six programs are (1) Knowledgebased Workplace, (2) "Infocomm Education," (3) "Electronic Services Delivery," (4) "Technology Experimentation," (5) "Adaptive and Robust Infocomm Infrastructure," and (6) Operational Efficiency Improvement" programs. Singapore provides e-government in Singapore intends to deliver services to three main groups: (i) citizen (G2C), (ii) business (G2B) and (iii) employees (G2E) [12]

In Indonesia, for the first time e-government was introduced to public administration by Presidential Decreenumber 6/2001 on Telematics, which states that the government of Indonesia has to use telematics technology to bolster good governance. For further uses, e-government has been employed for various purposes in government offices. For Indonesia, e-government implementation is needed at least for the following reasons: 1) to support the government change towards a democratic governance practices; 2) to support the application of authority balances between central and local government; 3) to facilitate communication between central and local governments; 4) to gain openness; and 5) transformation towards information society era [13]

The government has to perform a clean and transparent face which is responsive to any kinds of changes effectively by applying e-government system. The e-government services will stimulate the using internet when the government disseminates information through the website. E-government could also be employed as a control measure. For example, aRegent (Head of Regency Level) could see the tax this year and compared to data the year before and also citizens could do it for different purposes. The system also could maintain an integrative linkage from the information center to district or vise versa and with other districts also with all departments [13]

The Ministry of Communication and Information of Indonesia has some strategic plan to develop egovernment as follows: 1) to develop a good service system with reasonable cost; 2) to develop management system of central and local government; 3) to optimize the use of information technology especially inter governmental system; 4) to improve the participation of private sector and information technology industry; 5) to develop manpower capacity in the central and local government [13]
E-government instalment was done as one of the attempts of the bureaucratic reform acceleration program in Indonesia. E-government will improve efficiency and effectiveness of Government service through the online application of electronic systems in the government institutions and the quality of public services [14]. Thee-government instalment in Indonesia is demanded for some reasons: to support the government's change to democratic governance; to support the application of authority balances between central and local government; to facilitate communication between central and local governments; to gain openness; and transformation towards an information society era [15].

\section{Personal Privileges Security}

E-government will embrace the personal data records. The recording includes text messages, phone calls, and internet uses; these fields could be accessed by the government to investigate and solve the security threats. For example, the European Union has Instruction on Data Protection (1998) which gives the authority to personal data assessment/accessbut unfortunately does notcoverthe instruction towards the misuse prevention [16].

To protect personal privileges, Singapore has implemented two-step access: One Time Password, SingPass, and password. Infocomm Development Authority (IDA) said that in the end of 2016, 60\% of 3.3 million SingPass (Singapore Personal Access) will require accessing data on the layer system that will make harder for fraudsters(Gemalto). In case of Indonesia, Indonesia has a set of personal information protection especially in the Act of 14 Year 2008 on Public Information Openness (KIP).

Indonesia also has a set of personal information protection as the Act covers it. Article 17. H. Information, when opened and given to the applicant public information, could reveal personal secrets, namely: "1. The history and condition of family members; 2. history, condition and treatment, medical treatment physical, and psychological person; 3. The financial condition, assets, income, and bank accounts someone; 4 . The results of the evaluation concerning capabilities, intellect, and on the ability of a person; and/or 5. The records concerning private person related to activities of the formal education and non-formal education units”[17] 


\section{The Impacts of E-Government}

Public authorities do not only have a duty to provide information but in some demands also have right to acquire information from other authorities. This principle could applies such as to ombudsmen, state auditors as well as to the common exchange of information between public administration. Freedom of information is a part of human rights. It is essential to access information from public authorities that are indispensable for exercising human rights and freedoms. This is particularly true for disadvantaged groups, and especially in countries where information does not flow freely. Freedom of information in ideal form includes the right to receive and to access information held by public structures [18].

The dilemma in the act of openness is between the public interest and loyalty towards a public employer. The servants have to keep a clear rule as the common guidance not due to interests. In a democratic society, open space is vital to control the government service as an effort to transparent and accountability governance which eventually drive to economic growth and create an efficient public sector [18].

We can see the advantages of Singapore eGovernment that led to the government acceptance or "trust" by the society. At the start of its eGovernment action plan in 2000, Singapore government has taken a substantial number initiatives for economic development and IT implementation before the launch of its e-Government programs. The economic development can be seen from the fact that Singapore was ranked the second most competitive economy in the world in "The World Competitiveness Yearbook 2004", published by the International Institute for Management Development1 (IMD) and seventh most competitive economy in the "Global Competitiveness Report" by World Economic Forum2 (WEF) [19].

Singapore has successfully developed e-government in a strong foundation. Singapore has planted adequate resources and showed commitment to improve the provision of public services online. Set up adequate policies, clear objectives and strategic planning are factors contributing to e-Government success. Singapore has also prepared to deal with future threats in e-government conduct [12].

Indonesia has installed e-government in medium level as developing country. Refering to Wahid (2008), the positive impacts of e-government in Indonesia includes several fields. First, boost the transparency by providing the programme and budgets of government which eventually eradicate corruption. Second, it drives the civil society to involve into larger governmental issues which could take part in actions, advisory, and control the implementation of programmes. Third, we find that this promotes a better relationship between government and business as it provides tourism information, economic and business profile, and investment opportunities. However, only a limited procurement information and bid invitations that are provided [20].

On the paradox, there are also some negative impacts of using e-government. First, the failure of contents which effects to the failure of many activities publicly or privately. Second, when the provision and the using of e-government do not thoroughly for all areas and only few citizens can access it, then the development only for them. Third, when the users come only from special groups such as urban residents or well educate people, then the others would not enjoy the facility for their advances. Fourth, open information of policy might be considered to render some information misuse. Fifth, it can also open the possibility of cyber attacks which would make not only failure but also could harm the governmental system and societal harmony. These figures mostly occurred in developing countries and Indonesia fall under the figures, but in the case of Singapore the users are prevalent in all areas.

\section{Law Enforcement}

The use of open government database might create chances to information misuse both governmental data and private data. Then, it requestsa law enforcement to protect the misleading data. Egovernment also has to include law enforcement as a set of information services. Singapore has set up legal trust-building initiatives provided by the government. A legal set onElectronic Transactions Act (ETA) issued in 1998 to provide a legal foundation for electronic signatures and to give predictability and certainty to electronic Contracts, Public Key Infrastructure (PKI) and Licensing of Certification Authority (CA). PKI, a widely recognized secure platform for e-commerce transactions, has been adopted by Singapore Government. There is a special emphasis on 'personal data protection', trust development by the use of 'trust marks' (TrustSg) and regulation of online content, Intellectual Property Rights (IPR). The copyright act which has been amended in 1999 aims to improve the enforcement measures for copyright owners in the digital environment, to facilitate the use of Internet for business and Computer Misuse Act assigned in 1998. It also addresses new and potential computer abuses like 
denial or interruption of computer services and unauthorized disclosure of access codes, Domain Names Under the IDA act whereas IDA has the power to authorize or regulate the registration, administration and management of domain names in Singapore. Singapore Network Information Centre (SGNIC) was set up in 1995. Its function is to administer the ".sg" domain and InfoComm Development Authority (IDA) Website (Information Economy) [19]

In domain protection, Indonesia has applied the article of information protection covered by The Act of information Openness (KIP) in 2008. The article 17 orders that each public agency shall provide access to the set an Applicant Public Information to get public Information with the exception including a. Public Information, when opened and provided toApplicant Public Information, may inhibit the process of law enforcement. b. Public Information, when opened and providedtoApplicant Public Information, may interfere to harm of intellectual property rights and protection of unhealthy competition; c.Public information, when openedand given to Applicant Public Information, may endanger the defense and state security. d. Public Information, when opened and provided to ApplicantPublic Information, may disclose wealth Indonesia's nature; e. Public Information, when opened and provided to Applicant Public Information, can be detrimental to endurance national economy. f. Public Information when opened and provided to Applicant Public Information, could harm the foreign relations interests. g. Information that when opened can reveal the contents of authenticdeed of a personal nature and the last will or one's will; $\mathbf{h}$. Information when opened and given to the Applicant Public Information could reveal personal secrets. i. Memorandum or letters between public bodies or intra Public Agency, which is by nature confidential unless against the decision of the Information Commission or the courts; j. Information may be disclosed by Constitution [17].

Moreover, Indonesia impose sanctions that is covered in the Article 51, that any person who deliberately uses Public Information in contravention of law shall be punished with imprisonment of 1 (One) year and / or a maximum fine of Rp5,000,000.00 (five million rupiahs). Next is the Article 52 Public bodies that intentionally did not provide and / or did not published in the form of Public Information, Public Information Regularly, obligatory Public Information Announced Immediately, obligatory Public Information Available each set time, and / or Public Information should be given on the basis of request in accordance with this Act, and resulted loss for the other person subject to imprisonment for a maximum 1 (One) year and / or a maximum fine of Rp 5,000,000.00 (five million rupiahs) [17]

\section{CONCLUSION}

The success story of Singapore in e-government is based on several conditions. Firstly, wide spread of internet use. Secondly, populations have been dealing with internet as their daily needs. Thirdly, the involvement of all kinds of public groups involved educational institutions, businesses, and citizens. Fourthly, the strong leadership to enforce egovernment system for the government to government, to citizens, and to businesses. On the other hand, Indonesia has a large number of populations with large territory separated by thousand islands needs to use of internet and egovernment system. Indonesia has a set of law to implement and enforce the implementation of egovernment including sanctions. However, there are some obstacles including the variety of literacy level, internet user level, budgets, human resources and the most important is the will of leaders.

Singapore has provided a satisfaction for its citizen to information access for education, business, and other necessities. Indonesia still provides the system, human resources, and budgets. Thus, Indonesia has to gain the supports from related sectors including government, educational institutions, businesses, civil societies, and citizens. In fact, that information needs are in variety level for Indonesian citizens. Mostly the highest information need to come from educational sectors, activists and businesses.

Indonesia must learn from any previous success egovernment system such as Singapore which gives satisfactory for citizens that in turn will give more trust to the government and advanced for whole the country. More over Indonesia can cooperate with Singapore as ASEAN member country and also as neighbour or even can wider cooperate with South Korea to develop e-government for advanced citizen’s services

\section{References}

[1] Rocca, P. and Morabito, F.A. (2015). Optimal Synthesis of Reconfigurable Planar Arrays with Simplified Architectures for Monopulse Radar Aplications, IEEE Trans. Antennas Propag., vol. 63, n. 3, pp. 1048-1058. 
[2] Isernia, T., Massa A., Morabito, F. A., and Rocca, P. (2011). On the Optimal Synthesis of Phase-Only Reconfigurable Antenna Arrays, Proceedings of The $5^{\text {th }}$ European Conference on Antennas and Propagation (EuCAP 2011), article $n^{\circ}$ 5781977, pp. 2074-2077, 10-15 April 2011, Rome, Italy

[3] Alexander, B..Freedom of Information. http://www.unesco.org/new/en/communicati on-and-information/freedom-ofexpression/freedom-of-information/.

[4] United Nations Development Programme. Access to Information and EGovernance.http://www.undp.org/content/un dp/en/home/ourwork/democraticgovernance/ focus_areas/focus_access_information.html

[5] Hill, Clauspeter. (2011).Access to Information Laws in Asia, Germany and Australia.Singapore: Konrad-AdenauerStiftung, www.hotfusion.com.sg.

[6] Article 19. (2011).Asia Pacific: Free expression and Law in 2011. https://www.article19.org/resources.php/reso urce/3026/en/asia-pacific:-free-expressionand-law-in-2011

[7] Mendel, Toby. (2015).Freedom of Information as an Internationally Protected Human Right. https://www.article19.org/data/files/pdfs/pub lications/foi-as-an-international-right.pdf.

[8] Tessensohn, John (1999).Tell Him the Truth, Even if it Offends Him. http://www.humanrightsinitiative.org/pr ograms/ai/rti/international/laws_papers/singa pore/john\%20tessensohn.pdf.

[9] Halachmi, Arie. (2004).E-Government Theory and Practice: The Evidence from Tennessee (USA).Zhongshan University (China) and National Center for Public Productivity of Rutgers University (U.S.A.), http://unpan1.un.org/intradoc/group s/public/documents/un/unpan019248.pdf.

[10] Pankowska, Malgorzata. (2008).National Frameworks' Survey on Standardization of e-Government Documents and Processes for Interoperability.Journal of Theoretical and Applied Electronic Commerce Research,
ISSN 0718-1876 Electronic Versión Vol. 3 / Issue 3 / December 2008 / 6482. http://www.scielo.cl/scielo.php?pid=S07 18-18762008000200006\&script=sci_arttext

[11] Yannoukakoua, Aikaterini, Arakab, Iliana. (2014).Access to Government Information: Right to Information and Open Government Data Synergy.

(http://creativecommons.org/license s/by-ncnd/3.0/).

[12] Ha, Huong\& Coghill, Ken. (2006).EGovernment in Singapore - A Swot and Pest Analysis, http://www.dlsu.edu.ph/research/journals/ap ssr/pdf/200612/science_4.pdf.

[13] Haryono, Tisyo\&Widiwardono, Kristianto, Y.. (2012).Current Status and Issues ofEGovernment in Indonesia.http://www.asean.org/?static_post =current-status-and-issues-of-e-governmentin-indonesia.

[14] Lubis, Firmansyah. (2013).Optimalisasi EGovernment di Indonesia.KementrianKomunikasidanInform atikaRepublik Indonesia

[15] Dahlan, Nariman. (2011). "Correspondence Analysis of Indonesian e-government Websites" Ritsumeikan Asia Pacific University.

[16] Hague, R.\&Harrop, M.. (2013).Comparative Government and Politics An Introduction, New York: Palgrave Macmillan.

[17] Undang-UndangNomor 14 Tahun 2008 tentangKeterbukaanInformasiPublik (The Act of Public Information Openness).

[18] Boserup, LouiseKrabbe. (2005).An Introduction to Openness and Access to Information. Danish Institute for Human Rights. http://www.rwi.lu.se/NHRIDB/Europe/Den mark/AnIntroductiontoOpennessandAccesst oInformation.pdf.

[19] Srivastava, ShirishC.\&Teo, Thompson H.S.. (2016).Citizen Trust Development for EGovernment Adoption: Case of Singapore, NUS Business School, National University 
of Singapore.

http://www.academia.edu/283350

5/Citizen trust development for_e-

government_adoption_Case_of_Singapore

[20] Wahid, Fathul. (2008).Evaluating Focus and Quality of Indonesian E-Government Website. Seminar Nasional Aplikasi Teknologi Informasi 2008 (SNATI,2008) ISBN: 979-756-061-6 Yogyakarta, 21 Juni 2008. 